\title{
UMBERTO ECO - BAUDOLINO: POSTMODERNÝ PRÍSTUP AUTORA (MEDIEVALISTU) K HISTORICKEJ LÁTKE
}

\section{Umberto Eco - Baudolino: a Postmodern Approach to the History by the Author (Medievalist)}

Keywords: Baudolino, Umberto Eco, postmodernism, historical novel, medieval history Contact: Univerzita Pavla Jozefa Šafárikav Košiciach; onuskova.gabriela@gmail.com

Umberto Eco v knihe O literatúre čitatel'om vysvetl'uje, akým spôsobom píše svoje romány. Pri románe Baudolino mal mnoho nápadov, ktoré chcel použit' ako ústredné témy knihy. Napokon ich však premenil na menšie, resp. „čiastkové zápletky“ a každej z nich venoval kapitolu, román tak obsahuje štyridsat' kapitol (Eco 2004: 299).

Profesionálne písanie o dejinách vychádza z detailného poznania dôkazov, tým sa vyúst'uje do ,schopnosti porozumiet' dobe v jej vlastných súvislostiach, hodnotit' ju na základe jej vlastných kritérií“ (Elton in Šuch 2017: 88). Dej príbehu sa odohráva v takej vzdialenej minulosti, že autor nemôže počítat's vlastnou čitatel'skou empíriou, ani empíriou sprostredkovanou pamätníkmi, ktorá by mohla zobrazenie overovat', vyrozprávaný príbeh sa opiera len o historické pramene (Bílik 2008: 12). Aby sa Eco čo najviac priblížil faktom, vychádzal z informácií v kronikách, čím tak čitatel'ovi oživil úsek zo stredovekých dejín.

V postmodernom románe ide o postavy, ktoré sú čitatel'ovi predstavené ako skutočné postavy, aby si čitatel' vedel predstavit' ich konkrétne miesto i čas pôsobenia ich reálnej existencie (Foucault 1996: 131). Historické udalosti, osobnosti a ich činy sa spisovatel' usiloval podat' čitatel'ovi čo najpresvedčivejšie, najautentickejšie. U. Eco priznáva, že strávil roky nad historickými dokumentmi, dialektickými dobovými slovníkmi, a vyberal tak najvhodnejší materiál, ktorý by mohol použit' vo svojom románe a zároveň sa čo najviac držat' faktov (Eco 2004: 302).

V súlade s teorémami Stanislava Rakúsa, aplikujúc ich na Baudolina, pod látku, ktorou rozumieme mimoliterárny podklad, by sme mohli zahrnút' stredoveký svet $\mathrm{v}$ časoch križiackych výprav. A k téme čiže literárne transformovaným životným javom 
vybraným z látky by sme priradili pôsobenie Fridricha I. Barbarossu na severe Talianska a jeho smrt' počas výpravy, zároveň hl'adanie král'ovstva kňaza Jána a svätého grálu, ked’že posledné dve udalosti vychádzajú z legiend, ktorými bol stredoveký človek obklopený.

Román chcel Eco „rámcovat““ stretnutím Baudolina s Fridrichom I. a dobytím Konštantínopola. Ale na to, aby hlavná postava dodržiavala reálny historický priebeh, bolo nevyhnutné vytvorit' v príbehu „štyridsat'ročnú prestávku“, ktorú autor (resp. ústami Baudolina) vyplnil vyrozprávaním príbehu o putovaní Baudolina do královstva sv. Jána (Eco 2004: 307). Eco v románe spája osoby, ktoré sa však s ohladom na doložené historické okolnosti nemohli reálne stretnút'. Postmoderná filozofia inšpirovaná Nietzscheho myšlienkami práve stiera tieto hranice kategórií času a priestoru. Nietzsche zastával názor, že tieto dve oblasti nemá zmysel oddel'ovat'. Preto $\mathrm{v}$ postmodernizme autori prepájajú postavy a udalosti z rôznych miest a časových úsekov, ktoré sú vyobrazené v rovnakej dobe a na rovnakom mieste, hoci reálne by ich stretnutie nebolo uskutočnitel'né.

Zo všetkých historických osôb prítomných na tretej križiackej výprave si Eco pri písaní Baudolina vybral práve rímsko-nemeckého cisára Fridricha I.: „Fridrich Barbarossa bol pre mňa d’alším magickým menom, pretože som sa narodil v Alessandrii. Preto som sa pustil do čítania o Barbarossovi, chcel som vyrozprávat' príbeh o pôvode môjho mesta, o jeho legendách a okrem iného aj o Gagliaudovi a jeho krave“"(Eco 2004: 300).

Barbarossa začal t'aženie v tretej križiackej výprave v roku 1189. Fridrich I. šiel so svojou družinou v čele armády spolu so skupinou priatel'ov. Dorazil k brehu rieky Salef skôr ako ostatní a potom nikto s istotou nevie, čo sa stalo. Možno cisár spadol z koňa do rieky a bol omráčený alebo ho strhol prúd s t’ažkým brnením, ked' sa chcel napit' vody. Cisár zomrel v roku 1190, a uzavrela sa tak jedna etapa tretej križiackej výpravy (Bridge 2019: 222).

Členovia Barbarossovej armády sa bud' vrátili domov, alebo odplávali do Palestíny. Čast' z nich sa začala búrit' a až pateticky lipla na posmrtných pozostatkoch král'a. Viezli so sebou jeho telo zakonzervované v octe. V Antiochii sa cisárovo telo začalo rozkladat', a preto ho narýchlo pochovali v miestnej katedrále (Bridge 2019: 222223).

Popri Alessandrii Eco do deja zakomponoval aj Konštantínopol, pričom objavil osobu Niketu Chóniata a jeho dielo Chroniké diegesis (Eco 2004: 301). Niketa Chóniatas bol byzantský kronikár, ktorý spísal udalosti o tretej a štvrtej križiackej výprave. Opisoval, ako križiaci Barbarossy ponižovali l’ud aj ako prežil ich rabovanie 
v Konštantínopole. Posledné roky strávil v exile v meste Nicea. ${ }^{1}$ Vo svojej knihe opisuje aj to, ako katolíci rabovali pravoslávne kostoly: „... priam neznesitel’né bolo to, že niektorí z nich skákali na svätý prestol a tancovali na ňom, šialene poskakujúc a vyspevujúc akési barbarské piesne, a tak činili peleš lotrovskú na mieste svätom ...“ (Chóniatas in Aleš 2000: 106).

Eco práve pri podobnom rabovaní opisuje stretnutie hlavnej postavy s kronikárom. Baudolino zachránil Niketu pred smrt’ou: „Práve on ho teraz ochránil pred hnevom útočníkov, schoval ho na bezpečnom mieste, prichýlil ho u svojej rodiny a navrhol mu, že ho vyvedie z Konštantínopola“" (Eco 2019: 8).

Ústrednou postavou románu je Baudolino. Eco z patróna Alessandrie - sv. Baudolina - urobil Gagliaudovho syna a zároveň adoptívneho syna Fridricha I. Barbarossu.

Svätý Baudolino bol pustovníkom na svereozápade Talianska. Pôvodom bol $\mathrm{z}$ bohatej rodiny, ale $\mathrm{v}$ prospech chudobných sa vzdal svojho majetku. Baudolino bol opisovaný ako človek ,úžasnej svätosti““ a jeho osobnost’ sa vyznačovala mnohými zázrakmi, ked’že bol obdarený jasnozrivost'ou. Baudolino zomrel okolo roku 740, pochovaný je v lokalite Forum Fulvii. ${ }^{2}$

Baudolino v románe sa stretáva aj so svätým Baudolinom: ,Ja mám videnia ako vtedy ked' som videl jednorožca a druhý raz ked' som videl Svätého Baudolina, ktorý sa mi prihovoril a povedal mi skurvy syn, pôjdeš do pekla (...), ale potom mi odpustil a videl som ho ešte viac ráz v súmraku, ale len ak bola vel'ká hmla alebo aspoň mrholilo, nikdy nie vtedy ked’ žiarilo oves et Boves“ (Eco 2019: 7-8). Hoci jeho otec Galiaudo považoval syna za hlupáka a za jeho vidiny ho potrestal: „ked’ som však rozprával svojmu otcovi Galiaudovi že som videl svätého Baudolina, vyplatil ma tridsiatimi ranami po škrani a kričal ó, panebože, práve mne sa musel ujst' syn ktorý má videnia a nevie ani len Podojit' krawe kravu“" (Eco 2019: 8). V Baudolinovi je v texte mnoho gramatických chýb, lebo hoci je Baudolino obdarený múdrost'ou, pri písaní vlastnej kroniky si nie je istý, ako sa niektoré slová píšu správne. Pri vyjadrovaní, či už písomnom alebo ústnom, je použitých aj viacero jazykov, latinčina, nemčina, hebrejčina, taliančina a iné. Baudolino je obdarený schopnost'ou glosálie, čiže na počkanie hovorí cudzími jazykmi.

Románový Baudolino je typickou postmodernou postavou, ktorej osud by bol upadol do zabudnutia, nebyt' jeho stretnutia s Fridrichom I. Barbarossom. Baudolino stretol Fridricha v lese pri Fraschette. Cisár rodičom zaplatil a Baudolina vzal so sebou.

\footnotetext{
${ }^{1}$ Informácie na https://www.britannica.com/biography/Nicetas-Choniates.

${ }^{2}$ Informácie na https://www.zivotopisysvatych.sk/baudolino/.
} 
Slúbil, že ho adoptuje, vychová ho a dá mu najlepšie vzdelanie, aké len môže (Eco 2019: 8). Fiktívnost' jednotlivých udalostí v príbehu pramení v nemožnej pravdepodobnosti toho, čo sa odohráva medzi l'ud’mi: napríklad v stretnutiach osôb, ktoré sa z časových a priestorových dôvodov skutočne stretnút' nemohli (Foucault 1996: 44).

Baudolino žije „postmoderný život“, a teda taký, vd’aka ktorému by neexistoval, ak by nebol osobu $\mathrm{z}$ vyšších spoločenských kruhov, s vyššou spoločenskou dôležitost'ou (Foucault 1996: 136). Bolo nevyhnutné, aby sa stretol s niekým z tých mocných, aby jeho život nabral úplne iný smer.

Z hladiska Baumanovej ${ }^{3}$ typológie postáv postmodernej literatúry je Ecov Baudolino tzv. turista. Vyhl'adáva dobrodružstvá, opúšt’a domov, aby našiel nové dojmy, aby ich mohol niekomu vyrozprávat' (Bauman 2002: 50). Baudolino bažil po ceste do krajiny kňaza Jána. Navštívil ju, videl v nej rôzne tvory, zamiloval sa, ale musel ju opustit', po rokoch sa však opät' do tejto krajiny vydáva: „Musím dôjst' do ríše kňaza Jána. Ináč som prežil svoj život nadarmo“ (Eco 2019: 419).

Ako sme už uviedli, v románe bol Baudolino synom Gagliauda. Gagliaudo bol chudobným rol’níkom z Alessandrie, o ktorom koluje legenda, že sa mu podarilo zachránit' mesto pred cisárom Barbarossom. Obyvatelia Alessandrie nakŕmili Gagliaudovu kravu posledným obilím, čo našli v meste, a spolu s ňou ho poslali za hradby. Ked' ho s kravou cisárove vojská zajali, jeho uväznili a kravu zabili, aby si pripravili večeru. Počas jej pitvania videli, že žalúdok má plný obilia. Gagliaudo im povedal, že majú tol'ko vel’a zásob obilia v meste, že už ho dávajú aj kravám, lebo nevedia, kde ho skladovat'. Po tomto všetkom sa cisár rozhodol ukončit' obliehanie Alessandrie a stiahol svoje vojská (Bocchio 2018). Pre historické romány je typické, že postava z legendy sa dostáva do blízkosti historickej postavy tak, ako môžu vedl’a seba existovat' aj fiktívna udalost's reálnou (Doležel 1997: 601).

Postava Gagliauda, hoc z legendy vyznieva ako bystrý muž a v románe spolu $\mathrm{s}$ kravou Rosinou zachráni mesto, je $\mathrm{v}$ Baudolinovi postmoderne podstatne zironizovaná a do istej miery až sparodizovaná. Ked' umiera, v posledných slovách opisuje Baudolinovi, ako vyzerá raj: „Je presne taký, ako naša maštal', leskne sa čistotou a stojí v nej aj Rosina.A vidím tu aj tvoju dobrú mamu, potvora, teraz mi hovoríš, kde si dala vidly na hnoj...." (Eco 2019: 8).

Plán vonkajšej reality sa $\mathrm{v}$ historickej próze stáva doménou objektívnej deskripcie reálií alebo sugestívnej evokácie tzv. „obrazu doby“. Pri vysvetl’ovaní dejín sa bud' posilňuje sklon $\mathrm{k}$ faktografii, alebo vystupuje navonok sklon $\mathrm{k}$ fantazijnej

\footnotetext{
${ }^{3}$ Bauman rozlišuje v postmodernej tvorbe nasledujúce typy postáv: špacírkar, turista, tulák (Bauman 2002: 42$50)$.
} 
štylizácii lokálneho koloritu (exotizmus) miesta a čias so všetkým lyrickým inventárom, ktorý k tomuto postupu prináleží (Čepan 2002: 62). Stredoveké obdobie je plné legiend a fascinujúcich krajín či osôb, ktoré sprevádza zázračnost', exotickost'.

Postmoderna „zliepa“ mnoho žánrov a nie je to inak ani v tomto prípade. Prvky dobrodružného románu striedajú biografické časti, filozofické pasáže o „prázdne“, nachádzame tu aj mapy, listy, kroniku či skôr denník, a v neposlednom rade je tu priestor pre legendy.

Postmodernizmus upúšt’a od hl’adania jednotného chápania objektívnej skutočnosti, svet preň nemá žiadny stred, ale má len rôzne názory a stanoviská (Grenz 1997: 16). Umberto Eco ponúka vo svojom románe d’alšiu verziu, ako mohol Fridrich I. Barbarossa zomriet'. V príbehu sa dozvedáme, že Fridrich sa mohol bud' otrávit', alebo udusit' v spánku a do rieky ho už len vhodili, aby to vyzeralo, že sa utopil.

Eco do postmoderného historického románu vnáša aj prvky zázračna. Aby vyvolal u čitatel’a úžas, prekvapí ho „čudesnými bytost’ami“. Autor na vyvolanie zázraku vloží do deja niečo strašne cudzie alebo strašne vel'ké, vel'mi malé, nebezpečné alebo odporné (Herec 2008: 25). Ked’ ústredná postava - Baudolino prichádza do Královstva kňaza Jána, stretáva sa s rôznymi bytost’ami. Bazilišok, tvor s hlavou kohúta; chiméry, chrliace oheň, ktoré vyzerajú ako kombinácia leva, kozy a draka; bezhlavcov, ktorí majú tvár na hrudi; jednorožce; bytosti s ušami dlhými až po zem; satyrov; cynocephalov, kanibalov s tvárou psa. V krajine kňaza Jána nájde Baudolino aj mantikory - bytosti, ktoré vyzerajú ako muž a tiger dokopy. Tieto tvory a ich prítomnost' autor opisoval takto: „Obludy, áno, podobnejšie na zvieratá ako na l'udí a schopné rozmnožovat' sa rýchlejšie ako králiky. (...) pred mnohými storočiami ich kňaz presídlil sem, na hranice svojej ríše, aby svojím príšerným zjavom nevyrušovali jeho poddaných, ktorí sú - ubezpečujem t’a Baudolino - nádherní l’udia“ (Eco 2019: 8). Stretne sa aj s vtákom Rohom, ktorý sa opisuje ako orol s obrovskou silou. Baudolino na ňom s priatel'mi odletí do Konštantínopolu.

Král’ovstvo kňaza Jána je konštruktom, v ktorom medzisvetová identita niektorých postáv nejestvuje, ale v ktorých doplnkový historický fakt (,svetodejinné indivíduum" či entita) sú fikciou, ktorých dianie je umiestnené do nadprirodzených svetov, a napriek tomu sú konštruované ako historická fikcia; teda na princípoch žánrotvornej stratégie historického žánru (Bílik 2008: 49).

Eco sa rozhodol, že v románe budú prítomné postavy, ktoré budú vytvárat' falzifikáty, až napokon do príbehu zakomponoval príbeh o falzifikáte listu kňaza Jána: „V roku 1960 som riadil talianske vydanie (Le terre leggendarie) Lands Beyond Leye a Sprague Du Camp. Samozrejme tam bola kapitola o Král'ovstve kňaza Jána“ (Eco 
2004: 300). Téma putovania do krajiny kňaza Jána a legenda o jeho liste sa stali podstatnou čast'ou tvorenia jeho románu. Tento pravdepodobne nereálny svet je „V susedstve“ so skutočnými udalost'ami, čo je typické pre postmoderný priestor (Grenz 1997: 16).

Kňaz Ján a jeho legendárne král’ovstvo sa v dejinách objavovali od začiatku 12. storočia. Prvý raz sa o ňom zmienil biskup Oto z Freisingu a v legendu uveril aj pápež Alexander III. Marco Polo na prelome 13. a 14. storočia tvrdil, že kňaz Ján je chán Keraitov, mongolského kmeňa, ktorého súčast'ou boli nestoriánski kňazi (Lamb 2018).

Okrem putovania do ríše kňaza Jána Baudolino a jeho priatelia sa snažia nájst' relikviu svätý grál. Za svätý grál je označovaný kalich, z ktorého pil Ježiš pri Poslednej večeri a do ktorého tiekla Kristova krv, ked' bol na kríži. Niektoré pramene uvádzajú, že to nebol kalich, ale miska. Dodnes sa však nájdenie grálu a ani len jeho konkrétne miesto či vzhl'ad kalicha (misky) nepotvrdilo. ${ }^{4}$ Stredoveký človek bol obklopený legendami a priam posadnutý hl’adaním, nosením a vierou v relikvie.

V Baudolinovi sa grál opisuje ako: „Tak čo bol vlastne grál, tanier, alebo kalich? (...) Ak si to dobre premyslí možno vysvitne, že to bola kopija, ktorú mu Longinus zapichol do boku (...)“(Eco 2019: 222). Napokon sa ústredná postava rozhodne za grál prezentovat' drevenú misku z kuchyne svojho otca: „Dobre ju poumýval, aby nesmrdela vínom, lebo si hovoril, že ked' ju jedného dňa vyhlási za svätý grál, nemala by smrdiet' vínom, lebo od Poslednej večere prešlo vel’a času“ (Eco 2019: 226). Postmoderna ironizuje udalosti a aspekty súvisiace $\mathrm{s}$ náboženstvom. V románe nachádzame výsmech z falzifikátov krest’anských relikvií, výsmech zo svätcov.

Dej príbehu môže byt' sprostredkovaný rozprávačom, ktorému dôverujeme, ale aj takým, o ktorom pochybujeme, či to čo rozpráva, sa vo fiktívnom svete ozaj odohralo. Konkrétne, podl'a Boothovej typológie rozprávačov, ide o tzv. nespol'ahlivého rozprávača. Dej môže byt' podaný ako rozprávanie o skutočných udalostiach, ale aj ako vymyslená historka, ktorá si nárokuje vierohodnost' (Kubíček 2013: 103). Eco neistotu $\mathrm{v}$ relevantnost' historických informácií v Baudolinovi podčiarkuje v závere, ked' Niketovi jeho známy Pafnuzio tvrdí: „Nemysli si, že si jediný autor na tomto svete. Raz sa nájde na svete ešte väčší klamár ako Baudolino, ktorý jeho príbeh vyrozpráva“ (Eco 2019: 422).

Ako mohla vyzerat' smrt' Fridricha Barbarossu či král'ovstvo kňaza Jána, sú časti textu, ktorým čitatel' môže a nemusí dôverovat'. Postmoderní myslitelia sa hl'adaniu univerzálnej, konečnej pravdy vzdali, pretože sú presvedčení o tom, že nemožno nájst' nič iné než množstvo protichodných výkladov (Grenz 1997: 159). Eco postmoderným

\footnotetext{
${ }^{4}$ Informácie na http://www.magistra-historia.sk/tajomstvo-svateho-gralu/. 
spôsobom, ovplyvneným Nietzscheho filozofiou, tvorí dejiny, nachádza jednotlivých členov ret’azca istej historickej udalosti a pohráva sa s nimi presne v duchu Nietzscheho: „Niektoré diely ret’azca nachádzame znovu a znovu. Tie pozbierame dohromady a hl'adáme v náukách o l'udských potrebách dôvody vysvetl'ujúce takýto jav“ (Nietzsche 2011: 91). Smrt' Fridricha Barbarossu vyvoláva mnoho otázok a neexistuje jasný dokument, ktorý by opísal, ako naozaj cisár zomrel. Nietzsche tvrdí aj to, že neexistuje jedna všeobecná pravda, existujú len isté referencie, ktoré sme si v spoločnosti uzavreli ako pravdivé a všetko protichodné voči nim považujeme za lož. Tým, že Eco necháva čitatel'a na pochybách, mu dáva priestor na vytvorenie si vlastnej „,pravdy“, je na nás, ktorej referencii uveríme.

Eco zhromaždil známe fakty a doplnil ich o svoje domnienky, ktorými pomohol vysvetlit' nejasnosti, ale zároveň tak len ponúkol jednu z mnohých interpretácií tejto udalosti. Čo by sa mohlo a nemohlo udiat', nevie možno ani sám autor, ked’že čitatel'a necháva na pochybách aj tým, že Baudolino počas svojho rozprávania stále pripomína, že je obrovský klamár a že si vymýšl’a, ba dokonca klamstvá, ktoré vysloví, mu pripadajú také uveritel'né, až sa stanú pravdou. ,... mne sa vždy stávalo, že len čo som niečo povedal, hned' som to aj videl alebo som našiel list, ktorý to potvrdzoval (azda som ho aj sám napísal), zdá sa, že ostatní čakali len na to“ (Eco 2019: 29). Eco týmto posolstvom v románe nepriamo naznačuje, resp. vysvetl'uje čitatel'ovi, na akom princípe je založená celá jeho spisovatel'ská tvorba.

Historický román Baudolino môžeme považovat' za d’alšiu interpretáciu dejín, čo je ostatne ciel'om poznania histórie samej podl'a Nietzscheho, ked' tvrdil, že dejiny nedokážeme spoznat' a opísat' ich, vieme ich len interpretovat'. Vo fantastických textoch autor píše o udalostiach, ktoré sa v živote nemôžu prihodit', vychádzajúc z predpokladov každej doby o tom, čo sa môže a nemôže prihodit' (Todorov 2010: 33). Eco podal viac interpretácií smrti Fridricha I. Barbarossu, lebo uviedol možnú otravu jedom, udusenie alebo taký hlboký spánok, až si všetci mysleli, že zomrel a hodili ho do rieky, aby to vyzeralo ako nehoda pri plávaní.

Postmoderna ponúka rôzne pohl'ady na všetko, tu vidíme, ako pristupuje k spracovaniu histórie autor, ktorý je zároveň aj historikom. Zhromaždil a zosumarizoval historické fakty a udalosti a spojil ich do jedného časopriestoru. Do historickej látky vložil fiktívne momenty, ktoré mohli, ale nemuseli kreovat' dejiny a vyvolávajú v čitatel'ovi otázky ohl'adom ich relevantnosti. 


\section{Summary}

The article describes the processing of medieval history in the postmodern novel. I investigate the autor's approach in transforming the subject mater of history into fiction. For analyse I choose novel Baudolino by Umberto Eco. Eco wrote about Friedrich I Barbaross and his death during the Third Crusade. The search for the kingdom of priest John and the Holy Grail, In this article we see how the author, who is also a historian, approaches the processing of history. He gathered and summarized historical facts and events and combined them into one spacetime.

\section{Literatúra}

Eco, U. Baudolino. Bratislava: Slovart, 2019.

Aleš, P. Cirkevné dejiny III. Prešov: UNIPO, 2000.

Bauman, Z. Úvahy o postmoderní době. Praha: SLON, 2002.

Bílik, R. Historický žáner v slovenskej próze. Bratislava: Kalligram, 2008.

Bridge, N. Križové výpravy. Voznice: Leda, 2019.

Čepan, O. Literárne dejiny a literárna veda. Bratislava: Veda, 2002.

Doležel, L. Heterocosmica (Fikce a možné světy). Praha: Karolinum, 2003.

Eco, U. Meno ruže. Bratislava: Svetová knižnica SME, 2004.

Eco, U. O literatúre. Praha:Argo, 2004.

Foucault, M. Myšlení vnějšku. Praha: Herrmann \& synové, 1996.

Grenz, S.J. Úvod do postmodernizmu. Praha: Návrat domů, 1997.

Herec, O. Z teórie modernej fantastiky. Bratislava: Literárne informačné centrum, 2008.

Kubíček, T., Hrabal, J., Bílek, P. Naratologie, strukturální analýza vyprávění. Praha: Dauphin, 2013.

Nicolle, D. Tretí križová výprava 1191. Praha: Grada Publishing, 2005.

Nietzsche, F. Duševní aristokratismus. Olomouc: Votobia, 1993.

Nietzsche, F. Nečasové úvahy. Praha: Oikoymenh, 2005.

Nietzsche, F. Rané texty o hudbe a reči. Praha: Oikoymenh, 2011.

Nietzsche, F. Vôl’a k moci ako poznanie. Bratislava: Kalligram, 2014.

Todorov, T. Úvod do fantastické literatury. Praha: Karolinum, 2010. 
Welsch, W. Naše postmoderní moderna. Praha: Zvon, 1994.

Žilka, T. Modernizmus a postmodernizmus vo svetovej literatúre. Bratislava: Metodické centrum, 1994.

Šuch, J. Historické narácie - premenlivá alebo zmenšujúca sa miera fikcie? In: Šedíková-Čuhová, L. (ed.) Podoby faktuálneho naratívu. Bratislava: Chronos, 2017, s. 85-101.

Doležel, L. Mimesis a možné svety. Česká literatúra. 1997 (6), s. 600-624.

\section{Elektronické zdroje}

Bocchio, M. La legenda dell'astuzia di Gagliaudo. Dostupné z: https://medium.com (2020-02-28).

Lamb, A. The Search for Prester John. Dostupné z: https://www.historytoday.com (2020-02-28).

Baudolino, pustovnik. Dostupné z: https://www.zivotopisysvatych.sk/baudolino/ (202002-25).

Nicetas Choniates. Dostupné z: https://www.britannica.com/biography/NicetasChoniates (2020-02-25).

Tajomstvo svätého grálu. Dostupné z: http://www.magistra-historia.sk/tajomstvosvateho-gralu/ (2020-02-25). 